\title{
The Influence of Subjective and Objective Characteristics of Urban Human Settlements on Residents' Life Satisfaction in China
}

\author{
Xueming $\mathrm{Li}^{1,2}$ and $\mathrm{He}$ Liu ${ }^{1,2, * \mathbb{D}}$ \\ 1 School of Geography, Liaoning Normal University, 850 Huanghe Rd., Dalian 116029, China; \\ lixueming@lnnu.edu.cn \\ 2 Human Settlements Research Center, Liaoning Normal University, 850 Huanghe Rd., Dalian 116029, China \\ * Correspondence: liuhe1581@163.com; Tel.: +86-183-4081-1581
}

Citation: Li, X.; Liu, H. The Influence of Subjective and Objective Characteristics of Urban Human Settlements on Residents' Life Satisfaction in China. Land 2021, 10, 1400. https://doi.org/10.3390/ land 10121400

Academic Editor:

Anna Winiarczyk-Raźniak

Received: 31 October 2021

Accepted: 17 December 2021

Published: 18 December 2021

Publisher's Note: MDPI stays neutral with regard to jurisdictional claims in published maps and institutional affiliations.

Copyright: (c) 2021 by the authors. Licensee MDPI, Basel, Switzerland. This article is an open access article distributed under the terms and conditions of the Creative Commons Attribution (CC BY) license (https:/ / creativecommons.org/licenses/by/ $4.0 /)$.

\begin{abstract}
Under the guidance of people-oriented development concepts, improving residents' life satisfaction has gradually become the goal of urban governance. Based on Chinese household tracking survey data and national socio-economic statistics, this study used the entropy method, multi-layer linear regression model and geographically weighted regression model and discusses the spatial heterogeneity of the impact of objective environmental characteristics and subjective perceived characteristics of urban residential environments on residents' life satisfaction. It is of great importance to study the mechanisms through which subjective and objective characteristics of urban human settlements influence living satisfaction among residents. It is also important to discuss how to improve living satisfaction levels through the urban human settlements and to realize high-quality urban development. The research results show that in 2018, the overall level of life satisfaction among Chinese urban residents was relatively high. However, it is still necessary to continue to optimize the urban human settlements to improve residents' life satisfaction. The objective characteristics of the urban human settlements, such as natural environmental comfort and environmental health, have a significant positive impact on residents' life satisfaction. Residents' subjective perceptions of government integrity, environmental protection, wealth gap, social security, medical conditions and medical level, as well as residents' individual gender, age and health status also have a significant impact on residents' life satisfaction. The direction and intensity of effects of different elements of the urban human settlements and residents' personal attributes on urban residents' life satisfaction have different characteristics in different regions.
\end{abstract}

Keywords: human settlements; subjective perception; life satisfaction; multilevel linear regression model; China

\section{Introduction}

With the advancement of people-oriented development concepts, the focus of urban construction has gradually shifted to improving the well-being of residents. People's happiness is of great significance in promoting efficient and sustainable development of cities [1]. Life satisfaction, a parameter that can effectively measure residents' subjective perceptions of personal quality of life, is residents' judgment and cognition of differences between the expected and actual levels of life quality [2]. A high level of life satisfaction promotes residents' physical and mental health and extends life expectancy [3]. At present, the rapid expansion of Chinese cities has led to beneficial changes in urban human settlements [4]; however, there are problems such as traffic congestion and housing shortages, which, to a certain extent, hinder the sustainable development of cities and continuous improvement of residents' quality of life. Transforming, urban human settlements to improve residents' life satisfaction has gradually become a popular topic in urban planning and geography research [5].

Globalization, industrialization, informatization and urbanization make capital flow, material flow, information flow and people flow to cities. More than half of the world's 
population live in cities. Cities have become the most important gathering space for human beings on the earth [6]. Urban human settlements make residents live, rest, play and engage in social communication $[7,8]$. It encompasses many features including urban safety, public service facilities accessibility, natural environmental comfort, social and cultural environment comfort, transportation convenience and environmental health. Meanwhile, its core are the residents whose activities are within the scope of the city. The purpose of an urban human settlements is to meet the multi-level needs of residents by creating a more grounded, safe and comfortable living environment [9]. At present, theoretical research on urban human settlements is extensive [10]. To build evaluation index systems for urban human settlements, most scholars use the entropy method to determine the index weight and use the linear summing method to obtain the urban human settlements comprehensive score $[7,11]$, showing that the entropy method can be used as an effective objective method to more accurately reflect the current conditions of an urban human settlements. In addition, some scholars have found a close relationship between urban human settlements and residents' life satisfaction. Good urban human settlements are necessary for improving residents' life satisfaction [12-14]. By improving the urban human settlements, the satisfaction of residents can be enhanced. Studies have shown that the human settlements is closely related to residents' commuting-mode choice [15], individual health level [16], daily behavioral activities [15,17] and residents' happiness [18,19]. Some scholars have researched life satisfaction based on basic public service facilities. They have found that transportation convenience and facility fairness can influence residents' life satisfaction to a certain extent $[20,21]$.

Life satisfaction is the residents' overall perception and subjective evaluation of multiple aspects of their living environment [22]. With continuous improvement in residents' living standards, research on residents' subjective life satisfaction has gradually increased, becoming a popular topic in urban geography research. With the improvement of residents' living standards, scholars have gradually found that residents' life satisfaction is not only related to residents' personal attributes but is also closely related to environmental factors, among which the living environment is largely influential. The present study on the the factors that influence residents' life satisfaction examined three aspects: the impact of the objective characteristics of human settlements on life satisfaction, the impact of residents' subjective perceptions of the human settlements on life satisfaction and the impact of residents' personal attributes on life satisfaction.

\subsection{The Impact of the Objective Characteristics of Human Settlements on Resident Life Satisfaction}

Some scholars have found that differences in life satisfaction are in part derived from the living environment; that is, the internal associated characteristics of the living environment can have an impact on life satisfaction [14,23-25]. Boaiuto [26], based on questionnaire data, found a close relationship between human settlements quality and residents' life satisfaction through a multi-layer linear regression model. Through analysis, Mao found that the improvement of material environment can effectively improve the life satisfaction of male heads of households [27]. In addition, relevant objective elements of human settlements, such as population density, convenient traffic conditions, good public security environment, perfect infrastructure and a healthy natural environment, can all improve residents' living satisfaction to a certain extent [27-29]. Environmental pollution, such as domestic waste and wastewater discharge, may cause negative emotions among residents, which may negatively affect life satisfaction [30]. A harmonious and prosperous living environment can enhance the living comfort of residents, which in turn leads to residents feeling satisfied with their current living state and developing a positive outlook of the future [31-33]. Previous studies show that objective characteristics of human settlements can affect residents' life satisfaction to a certain extent. 


\subsection{The Impact of the Subjective Perception of Human Settlements on Resident Life Satisfaction}

Although objective material conditions are an important part of human settlements, an increasing number of scholars have found that the subjective perception of the environment also plays an important role in improving residents' life satisfaction [34,35]. Compared with the objective environment, residents' subjective perceptions of the environment are more likely to have a direct impact on life satisfaction [36]. Using a multilevel linear regression model, Feng found that residents' evaluation of their living environment was closely related to their own life satisfaction [37]. In addition, other studies demonstrated that residents' perceptions of government service quality and the social security have a more pronounced impacts on life satisfaction than objective environments [38-40].

\subsection{The Impact of Residents' Personal Attributes on Residents' Life Satisfaction}

Residents' personal attributes (such as gender, age, education level, marital status, income) have positive or negative relationships with residents' life satisfaction [41-45]. For example, health status can have a beneficial impact on life satisfaction. Compared with unhealthy people, residents with good health in the same environment tend to have a higher life satisfaction [46,47].

The above-mentioned research has laid a solid theoretical foundation and provided reliable references for research on the impact of subjective and objective characteristics of human settlements on the life satisfaction of residents. Changes in urban human settlements has led to the diversification of man-land relationships in urban areas. Subjective perceptions of the environment vary with the urban environment. Based on the objective environmental conditions and the differences in their subjective perceptions among various demographic groups, residents' life satisfaction differs and forms diversified patterns. By exploring the impact of urban human settlements on residents' life satisfaction, targeted improvements to urban human settlements can be made. This would be conducive to optimizing urban human settlements and improving residents' life satisfaction [48]. However, there are relatively few studies on the mechanisms though which human settlements affect residents' life satisfaction from the perspective of systems science and there is a lack of integrated research from this perspective. Therefore, the present study utilized residents' life satisfaction as a starting point and attempted to account for the lack of systematic scientific examination of current urban human settlements environmental planning and configuration. Based on the Chinese family tracking survey data and national social and economic statistics, the authors used the entropy method, multilevel linear regression model and geographically weighted regression model to explore the influence of objective characteristics of urban human settlements, subjective characteristics of urban human settlements and residents' personal attributes on residents' life satisfaction. This study aims to provide a reference for improving residents' quality of life and promoting high-quality and sustainable urban development. This paper focuses on the following questions: (1) whether various elements of urban human settlements influence residents life satisfaction differently and (2) whether there is spatial heterogeneity in the impact of various elements of urban human settlements on residents' life satisfaction.

\section{Data sources and Research Methods}

\subsection{Data Sources}

Research data were mainly obtained from the China Family Panel Studies (CFPS) implemented by the China Social Science Survey Center of Peking University in 2018 (http:/ / www.isss.pku.edu.cn/cfps/download, accessed on 17 September 2021), which is a major project of the Natural Science Foundation of China. The project collects data at the individual, family and community levels. The data include information on the economy, population, social and health of Chinese residents, which uses the computeraided personal interview (CAPI) technology as the primary form of data collection. CFPS is guided by the Declaration of Helsinki. The procedures of CFPS have been approved by the ethics committee of Peking University and all participants have obtained written 
informed consent [49]. In the initial design stage, CFPS drew on some advanced survey projects in the world, mainly including Panel Study of Income Dynamics (PSID), National Longitudinal Surveys of Youth (NLSY) and Health and Retirement Study (HRS) and made improvements on the basis of absorbing the successful experience of these survey projects, It provides researchers with more valuable family structure and family member information (http:/ / www.isss.pku.edu.cn/cfps/docs/20201215141314298129.pdf?CSRFT= Y9TH-ZEPW-101B-I8GJ-9UR8-CWN8-RDOC-D941, accessed on 12 December 2021). The project's research focuses include economic activities, family population and health statuses. The survey covers other provinces and cities, except Taiwan, Hong Kong and Macao and it can be regarded as representative data. The data are informative, extensive and authoritative, with a high degree of credibility and are widely used in social science and other research surveys [50,51]. The research focuses on the urban level, it also discusses the impact of personal attributes of urban residents, subjective perceptions and objective variables of the urban human settlements on residents' life satisfaction. Therefore, our research mainly used survey data from the CFPS individual self-answer database in 2018 to measure residents' life satisfaction and the subjective characteristics of urban human settlements. In addition, the statistical indicator data were derived from the 2019 China Statistical Yearbook, provincial and municipal statistical yearbooks, official websites of statistical bureaus and government bulletins to measure the objective characteristics of the urban human settlements.

Our research focused on data selected from 31 provinces (autonomous regions and municipalities directly under the Central Government), except for Taiwan, Hong Kong and Macao in China. According to the classification standards announced by the National Bureau of Statistics, the 31 regions of the mainland are divided into three major zones: East, Central and West. Among them, the eastern region includes a total of 11 provinces: Beijing, Tianjin, Hebei, Liaoning, Shanghai, Jiangsu, Zhejiang, Fujian, Shandong, Guangdong and Hainan; and the central region includes a total of 8 provinces: Shanxi, Jilin, Heilongjiang, Anhui, Jiangxi, Henan, Hubei and Hunan; and the western region includes a total of 12 provinces: Inner Mongolia, Chongqing, Sichuan, Guizhou, Yunnan, Tibet, Shaanxi, Gansu, Qinghai, Ningxia, Xinjiang and Guangxi (Figure 1).

\subsection{Variable Selection and Measure}

Generally speaking, human settlements consist of two characteristics: the objective characteristics of human settlements and the subjective characteristics of human settlements. A high-quality urban human settlement can improve residents' life satisfaction to a certain extent $[52,53]$. Residents' subjective perceptions of urban human settlements also have an indirect effect on life satisfaction. The more positive the residents' evaluation of the human settlements, the higher is their level of life satisfaction [43,54]. In addition, there are differences in residents' life satisfaction stemming from personal attributes [55-57]. In summary, this study selected residents' life satisfaction as the response variable with objective characteristics of urban human settlements and subjective characteristics of urban human settlements as the explanatory variables and residents' personal attributes were the control variables.

1. Explained variable: residents' life satisfaction

The life satisfaction values of residents in this study mainly came from a question in the CFPS questionnaire: their satisfaction with their current living status. The CFPS questionnaire contained five subjective evaluation ratings: very dissatisfied, not very satisfied, generally satisfied, quite satisfied and very satisfied, with values of 1, 2, 3, 4 and 5, respectively: the higher the value, the higher was the life satisfaction.

2. Explanatory variables: objective and subjective characteristics of urban human settlements

(1) Objective characteristics of urban human settlements

Objective characteristics of urban human settlements consists of the basic conditions needed for people to survive $[58,59]$. Urban human settlements are a multi-dimensional 
complex composed of safety, service facilities, natural environment, human environment, traffic conditions and environmental health [60-63]. Among them, urban safety is the key indicator of whether the urban human settlements are suitable for living [64]. The convenience of public service facilities is the basic condition of urban living environment, which provides convenience for residents to carry out medical, education, shopping and other activities. The comfort of natural environment provides comfortable and comfortable living environment for residents. The comfort of social and cultural environment is the characteristic direction of building urban residential environment, which has an important impact on residents' willingness to settle down [65]. Traffic convenience provides convenience for residents' daily travel activities. Environmental health is the primary condition for residents to carry out outdoor activities and normal life. Therefore, the study believes that the objective characteristics of urban human settlements should include six aspects, that is, a city with high-quality human settlements should be a safe city, a city with convenient life, a city with pleasant nature, a city with harmonious society, a city with convenient travel and a city with healthy environment (Figure 2). On this basis, based on statistical yearbook data, following the principles of comparability, scientificity and systemicity and constructs an objective characteristics of urban human settlements index system from 6 perspectives: urban safety, accessibility of public service facilities, comfort of natural environment, comfort of social and human environment, convenience of transportation and environmental health (Table 1).

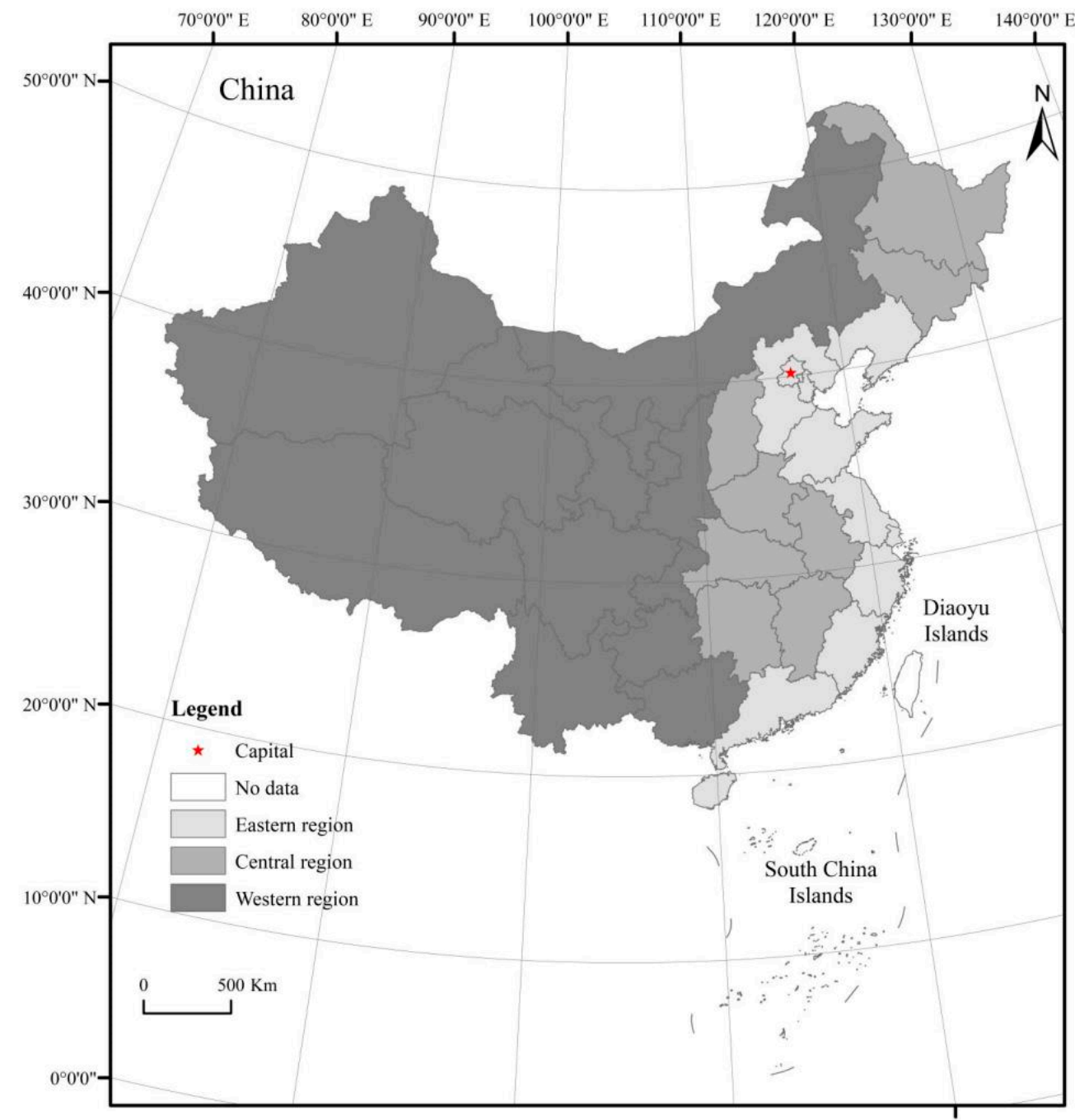

Figure 1. Study area. 
(2) Subjective characteristics of urban human settlements

Subjective characteristics of urban human settlements mainly consist of the nonmaterial social culture and environment along with the residents' subjective perception of the development status of objective human settlements [66]. Based on the theoretical framework of life satisfaction (Figure 3), it can be learned that residents' subjective perception of urban human settlements, that is, the subjective characteristics of urban human settlements come from the objective characteristics of urban human settlements. Therefore, the indicators of the subjective characteristics of urban human settlements are selected on the basis of the connotation of objective characteristics and follow the principle of accessibility. Based on the CFPS questionnaire data, the subjective characteristics of urban human settlements index system was divided into 10 system layers: government integrity, environmental protection, wealth gap, employment, education and teaching, medical problems, housing supply, social security, medical satisfaction and medical level (Table 1). The indexes were assigned according to degree of satisfaction. Based on this, the selected variables were reliably tested using Cronbach's coefficient and the validity test using the Kaiser-Meyer-Olkin (KMO) and Bartlett spherical tests. The coefficient of the data was 0.825 , higher than the evaluated standard value of 0.700 ; thus, it passed the reliability test. Furthermore, the KMO value was 0.866 and a significant Bartlett test indicated that the data could be used for factor analysis with good validity.

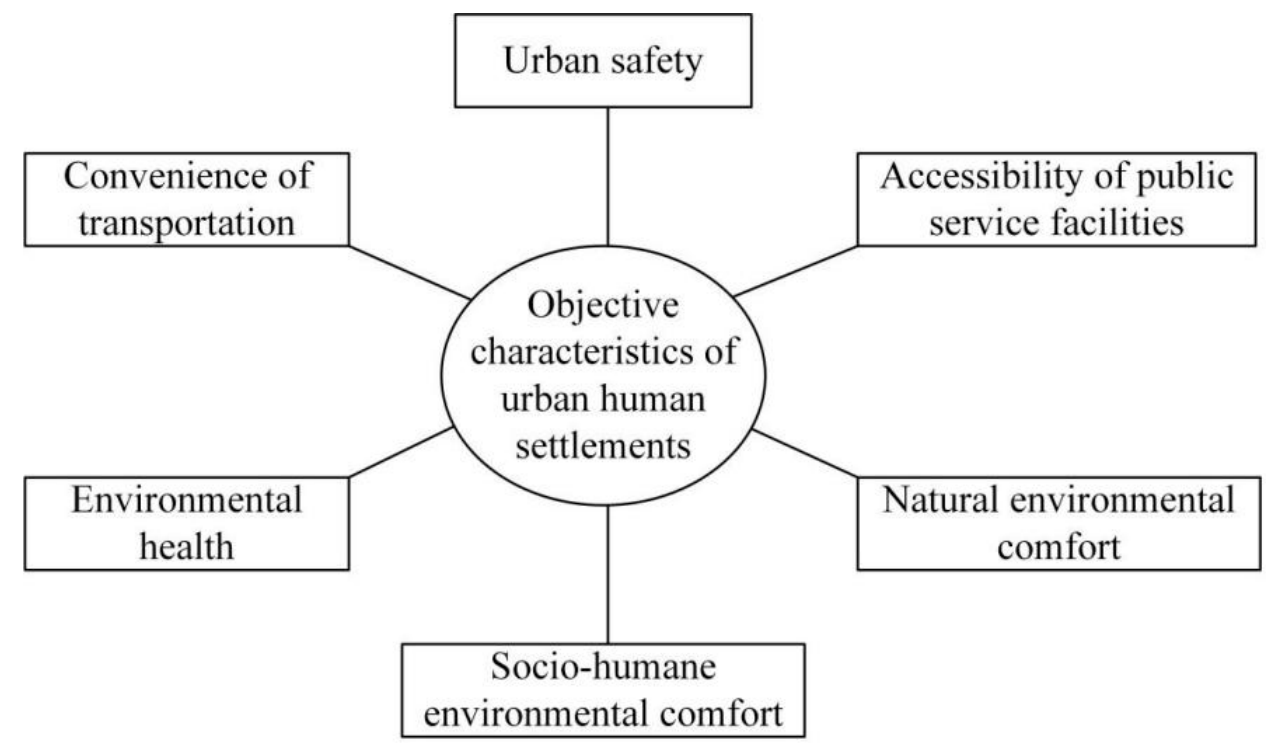

Figure 2. Connotation of the objective characteristics of the urban living environment.

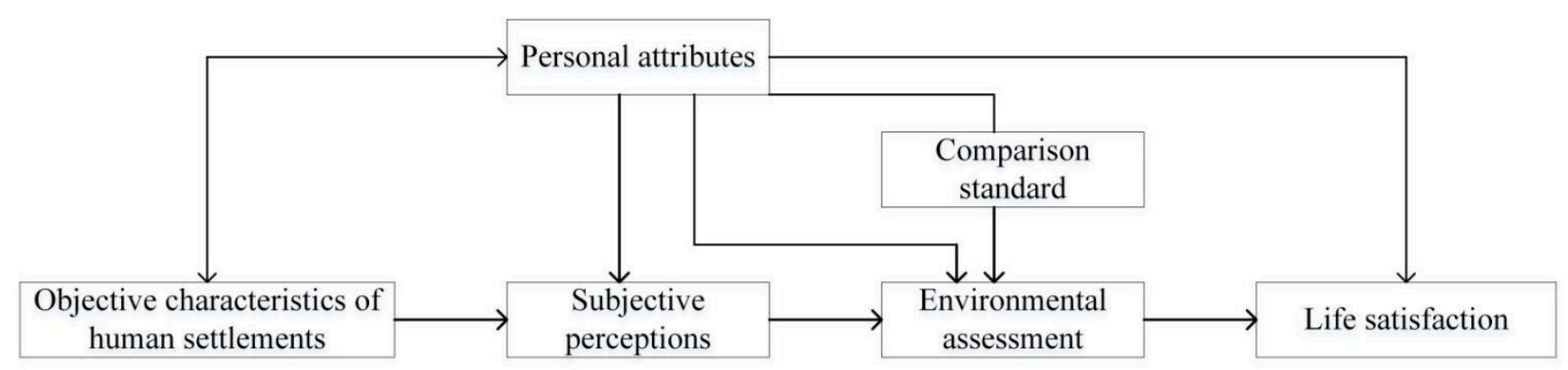

Figure 3. Campbell's Model. 
Table 1. Description of related variables

Target Layer

System Layer

Urban safety

Accessibility of public service facilities

Objective characteristics

of human settlements

Natural environmental comfor

Socio-humane environmental comfort

Convenience of transportation

Environmental health

Indicator Level

Public safety spending proportion (\%), Number of traffic accident deaths (person), Number of traffic accident injuries (person), Direct property damage from traffic accidents (10,000 yuan), Other loss commutation from forest fires (10,000 yuan), Direct economic loss from earthquake disasters (10,000 yuan), Number of geological disasters (number), Number of environmental emergencies (number)

Number of occupational (assistant) physicians per 1000 people (person), Number of registered nurses per 1000 people (person), Number of hospital beds per 1000 people (beds), Public library holdings per capita (book), Postal services per capita (yuan), Internet penetration rate $(\%)$, Urban water penetration rate $(\%)$, Urban gas penetration rate $(\%)$

Green coverage rate of built-up areas $(\%)$, Per capita green park area $\left(\mathrm{m}^{2}\right)$, Daily treatment capacity of urban sewage $\left(10,000 \mathrm{~m}^{3}\right)$, Harmless treatment rate of domestic waste $(\%)$

High-level of industrial structure, Per capita GDP (yuan/person), Unemployment rate (\%), Average wage of on-the-job workers (yuan) Number of libraries per 10,000 people (number), Number of museums per 10,000 people (number), Residential disposable income per capita (yuan), Proportion of expenditure on science and technology education (\%), Number of effective invention patents (number) Road area per capita $\left(\mathrm{m}^{2}\right)$, Public transport vehicles per 10,000 people (unit), Road network density $\left(\mathrm{km} / \mathrm{km}^{2}\right)$

Wastewater emissions per capita (ton), Sulphur dioxide emissions per capita $\left(\mathrm{m}^{3}\right)$, Smoke and dust emissions per capita $\left(\mathrm{m}^{3}\right)$, Comprehensive industrial solid waste utilization rate (\%)

Government Integrity

Environmental protection

The gap between rich and poor

Employment issue

Subjective characteristics of human settlements

Education and teaching

Medical issues

Housing supply

Social security

Medical satisfactions Medical level

Degree of government integrity in China $(0-10$, where not severe $=0$, very severe $=10)$

Degree of environmental problems in China $(0-10$, where not serious $=0$, very serious $=10$

Degree of the wealth gap in China $(0-10$, where not severe $=0$, very severe $=10)$

Degree of employment problem in China $(0-10$, where not serious $=0$, very serious $=10)$

Degree of education problems in China $(0-10$, where not serious $=0$, very serious $=10)$

Degree of medical problems in China $(0-10$, where not serious $=0$, very serious $=10)$

Degree of housing problem in China $(0-10$, where not serious $=0$, very serious $=10)$

Degree of social security in China $(0-10$, where not severe $=0$, very severe $=10)$

Satisfaction with the conditions of medical care (don't know $=0$; very dissatisfied $=1$; dissatisfied $=2$; general $=3$; satisfied $=4$; very satisfied $=5$ ) $($ don't know $=0$; very bad $=1 ;$ bad $=2 ;$ general $=3$; good $=4$; very good $=5)$

\section{Gender}

Educational background Marital statu Income level

Type of housing inhabited Health status

\section{Male $=1 ;$ Female $=2$ \\ Age of the investigator}

Below junior high school $=1$, High school $=2$, College $=3$, University $=4$, Graduate student $=5$

Unmarried $=1$, Cohabitation $=2$, Married ( with a spouse) $=3$, Divorced $=4$, Widowed $=5$ Per capita net household income (yuan)

Bungalow $=1$, Flat $=2$, Small building $=3$, Courtyard house (type of Chinese residence) $=4$, Villa $=5$ Unhealthy $=1$, General $=2$, Relatively healthy $=3$, Healthy $=4$, Very healthy $=5$ 
3. Control variables: residents' personal attributes

It has been shown that residents' personal attributes also have an impact on life satisfaction [66,67]. These include age, gender, educational background, marital status, health status and income level. The relevant variables were described and assigned as shown in Table 1.

\subsection{Sample Socio-Economic Attributes}

By pre-processing the data of the 2018 Chinese Family Tracking Survey, 13,150 samples were obtained after removing the missing values and the socio-economic attributes of the samples were statistically analyzed (Table 2). As shown in Table 2, men and women accounted for $49.87 \%$ and $50.13 \%$, respectively, of the study sample, indicating a balanced ratio of men and women. Residents of all ages are evenly distributed; the number of residents with higher education in the sample was relatively small; residents who were married (with spouses) accounted for the majority of the sample; the residents' net household income per capita was dominantly in the ranges of 10,000-19,999 and 40,000 yuan or more; the proportion of residents with flat housing and a relatively decent health status was fairly large.

Table 2. Sample socio-economic attributes statistics.

\begin{tabular}{|c|c|c|c|c|c|c|c|}
\hline Properties & Categories & Quantities & Ratio & Properties & Categories & Quantities & Ratio \\
\hline \multirow[b]{2}{*}{ Gender } & Male & 6558 & 49.87 & \multirow{7}{*}{$\begin{array}{l}\text { Per capita net } \\
\text { household income }\end{array}$} & Less than 5000 yuan & 658 & 5.00 \\
\hline & Female & 6592 & 50.13 & & 5000 9999 & 1433 & 10.91 \\
\hline \multirow{5}{*}{ Age } & Under the age of 30 & 2250 & 17.11 & & $10,000 \sim 19,999$ & 3265 & 24.83 \\
\hline & $30 \sim 40$ & 2785 & 21.18 & & $20,000 \sim 29,999$ & 2507 & 19.06 \\
\hline & $41 \sim 50$ & 2682 & 20.4 & & $30,000 \sim 39,999$ & 1794 & 13.64 \\
\hline & $51 \sim 60$ & 2360 & 17.95 & & More than 40,000 yuan & 3493 & 26.56 \\
\hline & More than 60 years of age & 3073 & 23.36 & & Bungalow & 2912 & 22.14 \\
\hline \multirow{6}{*}{$\begin{array}{l}\text { Education } \\
\text { background }\end{array}$} & Below junior high school & 3273 & 24.89 & \multirow{6}{*}{$\begin{array}{l}\text { Type of housing } \\
\text { inhabited }\end{array}$} & Flat & 4012 & 30.51 \\
\hline & High school & 1418 & 10.78 & & Small building & 2624 & 19.95 \\
\hline & College & 1076 & 8.18 & & $\begin{array}{c}\text { Courtyard house (type of } \\
\text { Chinese residence) }\end{array}$ & 128 & 0.97 \\
\hline & University & 973 & 7.41 & & Villa & 97 & 0.75 \\
\hline & Graduate student & 91 & 0.69 & & Other & 3377 & 25.68 \\
\hline & Deficiency & 6318 & 48.05 & & Unhealthy & 1763 & 13.41 \\
\hline \multirow{5}{*}{ Marital status } & Unmarried & 1358 & 10.33 & \multirow{5}{*}{ Health status } & General & 1803 & 13.71 \\
\hline & Cohabitation & 75 & 0.57 & & Relatively healthy & 6060 & 46.08 \\
\hline & Married (with spouse) & 10,744 & 81.70 & & Healthy & 1975 & 15.02 \\
\hline & Divorced & 653 & 4.97 & & Very healthy & 1549 & 11.78 \\
\hline & Widowed & 320 & 2.43 & & & & \\
\hline
\end{tabular}

\subsection{Research Methods}

\subsubsection{Entropy Method}

As an objective weight assignment method, the entropy method determines the weights of objective characteristics of urban human settlements according to the size of the indicator information, which can effectively avoid the uncertainty and artificial subjectivity of subjective assignments and improve the rationality of decision-making. The entropy method can effectively determine the degree of discretization of the index and the influence of the index on comprehensive evaluation results [68]. It is applicable to the comprehensive evaluation of research subjects based on multiple index systems and is widely used in scientific research $[69,70]$. Therefore, the study chose the entropy method to determine the objective characteristic indicators of the weight of urban human settlements. The entropy method is described as follows: 
(1) To eliminate the dimensional differences between various indicators, the range standardization method was used to deal with indicators.

$$
\begin{aligned}
& \text { Positive indicators : } x_{i j}^{\prime}=\left(x_{i j}-\min x_{i j}\right) /\left(\max x_{i j}-\min x_{i j}\right) \\
& \text { Negative indicators : } x_{i j}^{\prime}=\left(\max x_{i j}-x_{i j}\right) /\left(\max x_{i j}-\min x_{i j}\right)
\end{aligned}
$$

where $x_{i j}^{\prime}$ is the value after normalization, $x_{i j}$ is the original value and max $x_{i j}$ and min $x_{i j}$ are the maximum and minimum values in the original value.

(2) To avoid invalidating the logarithmic truth value when the standardized indicator values are logarithmic, the standardized indicator values are translated as follows [71]:

$$
A_{i j}^{\prime}=x_{i j}^{\prime}+M
$$

where $A_{i j}^{\prime}$ is the translated value and $M$ is the translated amplitude, which takes a value of 1 .

(3) The weight of the $j$ th indicator for the $i$ th city is calculated:

$$
y_{i j}=A_{i j}^{\prime} / \sum_{i=1}^{k} A_{i j}^{\prime}
$$

(4) The entropy value of indicator $j$ is calculated:

$$
h_{j}=-m \sum_{i=1}^{k} y_{i j} \ln y_{i j}, m=\frac{1}{\ln k}, m>0
$$

(5) The difference coefficient is calculated:

$$
g_{j}=1-h_{j}
$$

(6) The weight of indicator $j$ is calculated:

$$
w_{j}=g_{j} / \sum_{j=1}^{n} g_{j}
$$

(7) The objective characteristics of urban human settlements score is calculated:

$$
U=\sum_{j=1}^{n} w_{j} A_{i j}^{\prime}
$$

\subsubsection{Multilevel Linear Regression Model}

Since residents' life satisfaction is an ordered continuous variable valued from 1 to 5 and belongs to ranked data: the larger the value, the higher the residents' life satisfaction. Multilevel linear regression was used to estimate the urban human settlement's influence on the subjective and objective characteristics of residents' life satisfaction [72]. The model is as follows.

$$
Y=\alpha+\beta_{1} X_{1}+\beta_{2} X_{2}+\cdots+\beta_{i} X_{i}+\varepsilon
$$

$Y$ is the dependent variable, the residents' life satisfaction; $X$ is the independent variable, the subjective and objective characteristics of urban human settlements; $\beta$ is the regression coefficient explaining each independent variable; $i$ is the number of independent variables; $\alpha$ is the constant term; $\varepsilon$ is the residual.

\subsubsection{Geographically Weighted Regression Model}

A geographical weighted regression (GWR) model account for the spatial characteristics of variables and reveal the spatial relationships between geographical phenomena and 
various elements. A GWR model was used to analyze the impact of spatial heterogeneity of urban human settlements on life satisfaction [73]. The model is as follows.

$$
Y_{i}=\beta_{0}\left(u_{i}, v_{i}\right)+\beta_{1}\left(u_{i}, v_{i}\right) x_{i 1}+\beta_{2}\left(u_{i}, v_{i}\right) x_{i 2}+\cdots+\beta_{k}\left(u_{i}, v_{i}\right) x_{i k}+\varepsilon_{i}
$$

$Y_{i}$ is the resident life satisfaction value, $\left(u_{i}, v_{i}\right)$ is the geographical coordinates of the city, $x_{i k}(k=1,2, \ldots)$ are the significant variables in the objective and subjective characteristics of the urban human settlements, $\beta_{k}\left(u_{i}, v_{i}\right)$ is the regression parameter of the city's center of mass $\left(u_{i}, v_{i}\right)$ and $\varepsilon_{i}$ is the random error term.

\section{Characteristics of Residents' Life Satisfaction}

\subsection{Overall Characteristics of Residents' Life Satisfaction}

The overall life satisfaction among Chinese residents was relatively high, with an average of 3.98. The largest percentage of the sample was quite satisfied (38.83\%), followed by very satisfied $(32.09 \%)$ and the smallest proportion of residents reported being very dissatisfied $(1.35 \%)$. The variation change of Chinese residents' life satisfaction ratio was 37.48 , showing a flat-peaked, thick-tailed and a left-skewed distribution trend; its skewness coefficient was -0.27 and the kurtosis coefficient was -2.81 , indicating that Chinese residents' life satisfaction was slightly negatively biased and flatly distributed (Figure 4).

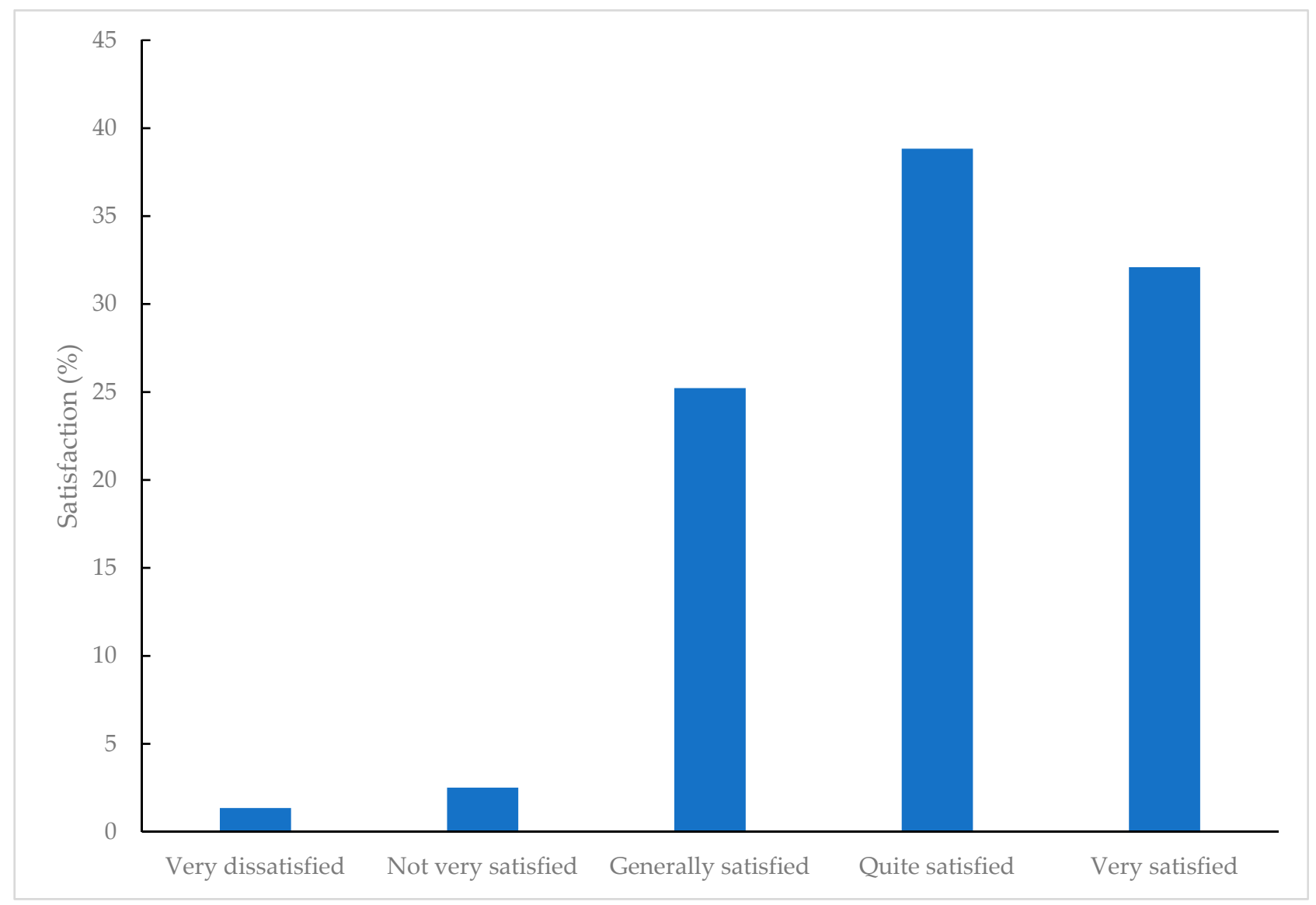

Figure 4. Life satisfaction distribution of Chinese residents.

\subsection{Population Differences in Residents' Life Satisfaction}

The analysis compared the subjective characteristics of different urban human settlements and the life satisfaction of residents with different personal attributes. One-way ANOVA was used to test whether there were differences in residents' life satisfaction with different groups (Table 3). 
Table 3. Comparison of life satisfaction characteristics of residents.

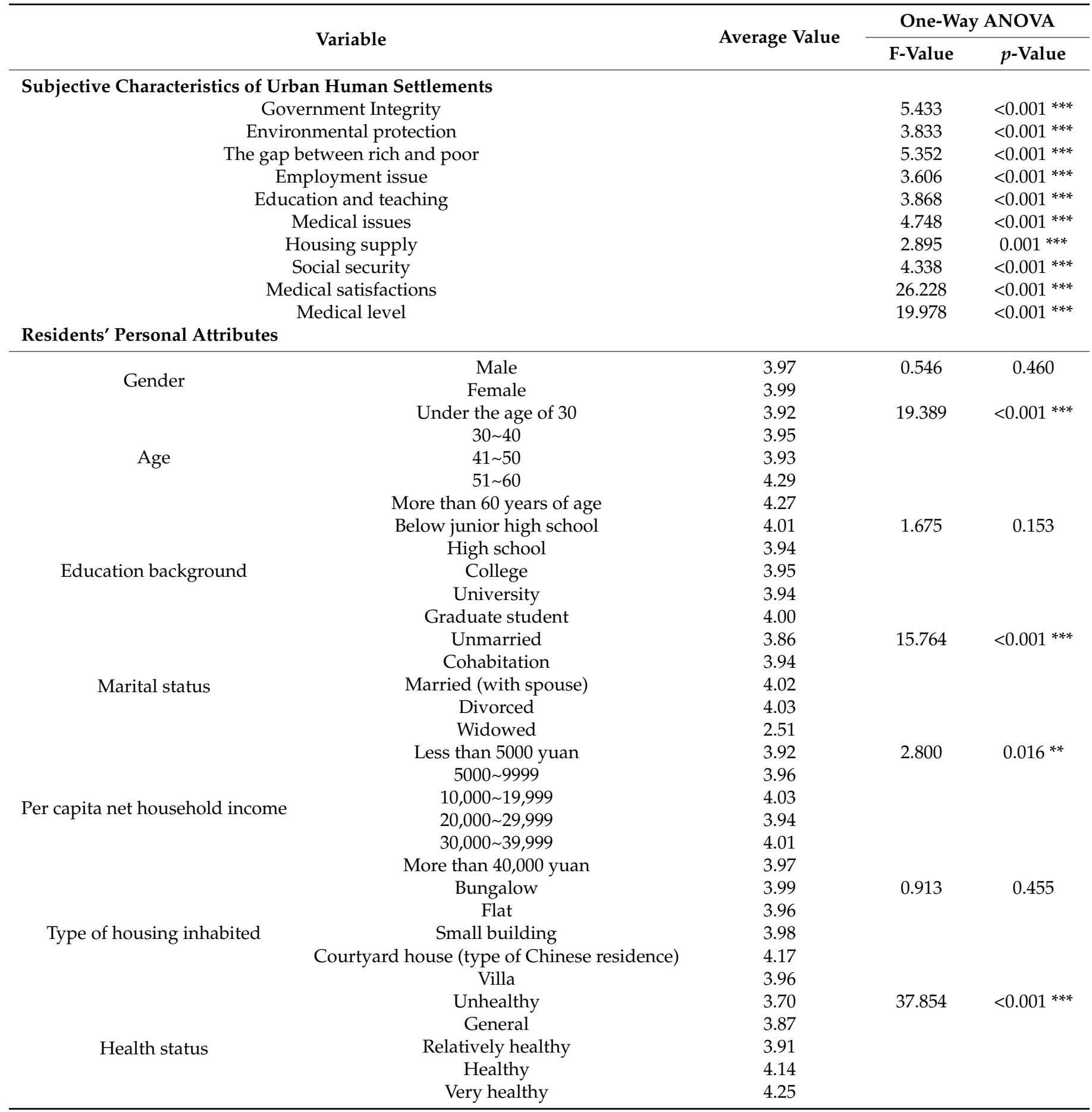

Note: ${ }^{* * *},{ }^{* *}$ respectively indicate $p<0.01, p<0.05$.

In terms of subjective characteristics of urban human settlements, there were significant differences in the life satisfaction of residents, with different evaluation levels of government integrity, environmental protection, wealth gap, employment issues, education and teaching, medical issues, housing supply, social security, medical satisfactions and the level of medical care. These significant differences in life satisfaction indicate that there is a strong correlation between the subjective characteristics of urban human settlements and residents' life satisfaction.

In terms of personal attributes, there were significant differences in life satisfaction among residents of different ages, marital status, income level and health status. Residents' 
life satisfaction was slightly higher among women than men, but not significantly, which is similar to the results of relevant studies [74]. The older the residents were, the higher their life satisfaction was [75]; in particular, the life satisfaction of residents over 50 years old was significantly higher than that of other age groups [76]. There was no significant difference in life satisfaction among residents with different educational backgrounds. Marital status had a significant effect on residents' life satisfaction, with married residents (with a spouse) and widowed spouses having higher life satisfaction than residents with other marital statuses. With an increase in income level, residents' life satisfaction exhibited an " $M$ " shape trend of rising and falling. The impact of housing type on residents' life satisfaction was not significant. The higher the health status of the residents, the higher was their life satisfaction. The differences in life satisfaction among residents with various health statuses was significant.

\section{Influencing Factors of Residents' Life Satisfaction}

\subsection{Analysis of the Impact of Human Settlements on Residents' Life Satisfaction}

Multiple linear regression was used to analyze the factors influencing residents' life satisfaction and explore the influence of subjective and objective characteristics of urban human settlements on residents' life satisfaction. First, the control variables (gender, age, education, marital status, income level, type of housing and health status) and residents' life satisfaction model (Table 4) were established, specifically model 1. Based on model 1, objective and subjective characteristics of urban human settlements were gradually added to models 2 and 3 . The F-test values of all the models passed the $1 \%$ significance level test, indicating that the models fit well.

Table 4. Multilevel linear regression estimation results.

\begin{tabular}{|c|c|c|c|}
\hline & Model 1 & Model 2 & Model 3 \\
\hline \multicolumn{4}{|c|}{ Objective Characteristics of Urban Human Settlements } \\
\hline Urban safety & & 0.158 & \\
\hline Accessibility of public service facilities & & 0.008 & \\
\hline Natural Environmental Comfort & & $0.031 * *$ & \\
\hline Socio-humane environmental comfort & & 0.036 & \\
\hline Convenience of transportation & & 0.141 & \\
\hline Environmental health & & $0.270 * * *$ & \\
\hline \multicolumn{4}{|c|}{ Subjective Characteristics of Urban Human Settlements } \\
\hline Government Integrity & & & $-0.019^{* * *}$ \\
\hline Environmental protection & & & $-0.012 * *$ \\
\hline The gap between rich and poor & & & $-0.020 * * *$ \\
\hline Employment issue & & & $-0.020 * * *$ \\
\hline Education and teaching & & & -0.004 \\
\hline Medical issues & & & -0.003 \\
\hline Housing supply & & & -0.001 \\
\hline Social security & & & $-0.012 *$ \\
\hline Medical satisfactions & & & $0.105^{* * *}$ \\
\hline Medical level & & & $0.042^{* *}$ \\
\hline \multicolumn{4}{|l|}{ Residents' Personal Attributes } \\
\hline Gender & $0.043^{* *}$ & $0.044^{* *}$ & 0.022 \\
\hline Age & $0.136^{* * *}$ & $0.137 * * *$ & $0.126^{* * *}$ \\
\hline Educational background & 0.002 & 0.003 & -0.005 \\
\hline Marital status & -0.037 & -0.037 & -0.018 \\
\hline Income level & 0.011 & 0.014 & 0.014 \\
\hline Type of housing inhabited & 0.007 & 0.008 & 0.008 \\
\hline Health status & $0.181^{* * *}$ & $0.181^{* * *}$ & $0.167^{* * *}$ \\
\hline Constant & 3.08 & 3.29 & 2.73 \\
\hline F-test value & $38.75^{* * *}$ & $21.10 * * *$ & $22.53^{* * *}$ \\
\hline Adj R-squared & 0.559 & 0.553 & 0.758 \\
\hline
\end{tabular}




\subsubsection{Analysis of the Impact of Personal Attributes}

According to the regression results, among residents' personal attributes, gender, age and health status have a significant impact on residents' life satisfaction, while educational background, marital status, income level and type of housing inhabited have a weak impact on residents' life satisfaction. Among these attributes, the effect of gender on residents' life satisfaction was significant at the $5 \%$ level, indicating that female residents are more satisfied with their lives than males. Age had a significant effect on residents' life satisfaction at the $1 \%$ level. The older the residents were, the higher their life satisfaction was, mainly because older residents, having lived for a longer time, have developed a deeper affection for their living environment, increasing their life satisfaction. Health status had a significant positive effect on residents' life satisfaction; the better was the health status of residents, the higher was their life satisfaction, which is consistent with the relevant conclusions [77].

\subsubsection{Analysis of the Impact of Objective Characteristics of Urban Human Settlements}

Based on model 1, objective characteristic variables of urban human settlements were added to model 2. The regression results showed that each system of objective characteristics of urban human settlements had different degrees of influence on residents life satisfaction. Among them, the effects of urban safety, accessibility of public service facilities, comfort of social and humanistic environment and convenience of transportation on residents' life satisfaction were weak and insignificant. This indicates that improving urban safety levels, enhancing the accessibility of public service facilities, optimizing social and humanistic environments and improving transportation will not necessarily lead to a significant increase in residents' life satisfaction.

Natural environmental comfort had a significant positive influence on residents' life satisfaction at the $5 \%$ level. The comfort level of natural environments can increase the the chance of travel among residents. A comfortable natural environment restores residents voluntary attention by evoking their involuntary attention, thus reducing their life stress to a certain extent and providing indirect support for their physical and mental health, which enhances their life satisfaction $[78,79]$.

Environmental health had the most significant effect on residents' life satisfaction. The $1 \%$ significance level test indicates that a healthy and comfortable urban environment can enhance residents' life satisfaction. Relevant studies show that there is a strong link between environmental health factors, such as air pollution and residents' life satisfaction [80,81]. They also show that a clean environment can improve residents' life satisfaction [38,82]. A good environment can meet the basic survival needs of residents to a certain extent. Therefore, it is necessary to enhance the level of environmental health and residents' perceptions of environmental health to improve their life satisfaction.

\subsubsection{Analysis of the Impact of Subjective Characteristics of Urban Human Settlements}

In model 3, the subjective characteristic variables of urban human settlements were added on the basis of model 1 . The regression results showed that except for education and teaching, medical problems and housing supply, the variables in the subjective characteristics of urban human settlements have significant positive or negative effects on residents' life satisfaction.

Government integrity had a significant negative impact on residents' life satisfaction and environmental protection had a significant impact on residents' life satisfaction at the $5 \%$ level; wealth gap and employment issues had the same degree of impact on life satisfaction and passed the $1 \%$ significance level test. Social security had a smaller impact on life satisfaction, but passed the $10 \%$ significance level test. In addition, employment conditions and medical levels had different degrees of positive effects on residents' life satisfaction. Therefore, to improve residents' life satisfaction, it is necessary to narrow the gap between the rich and the poor, strengthen government integrity, enhance environmental protection, 
improve the social security system, optimize medical conditions, improve the level of medical treatment and improve residents' subjective perceptions of human settlements.

In summary, analysis of the effects of subjective and objective characteristics of urban human settlements on life satisfaction indicated that objective environment characteristic variables have a positive impact on life satisfaction and subjective perception characteristics (except the medical satisfactions and medical levels) have a negative impact on residents' life satisfaction. Although there was no significant difference in the behavior of the variables, there were significant differences in their strength and level of significance. This shows that focusing on significant variables can more effectively improve life satisfaction.

\subsection{Analysis on the Impact of Sub Regional Urban Human Settlements on Residents' Life Satisfaction}

China is a vast country with distinct regional and complex human settlements characteristics. In order to explore whether different regional human settlements have different effects on residents' life satisfaction, the regions were divided into the east, middle and west divisions of China and the influences of objective characteristics of urban human settlements, subjective characteristics of urban human settlements and residents' personal attributes on residents' life satisfaction were analyzed by region; the results are shown in Table 5, where the F-test values are all significant at the $1 \%$ level and the fitting effect of each model is good.

Table 5. Regional regression results of residents' life satisfaction.

\begin{tabular}{|c|c|c|c|c|c|c|c|c|c|}
\hline & \multicolumn{3}{|c|}{ Eastern Region } & \multicolumn{3}{|c|}{ Central Region } & \multicolumn{3}{|c|}{ Western Region } \\
\hline & $\begin{array}{c}\text { Model } \\
4\end{array}$ & $\begin{array}{c}\text { Model } \\
5\end{array}$ & $\begin{array}{c}\text { Model } \\
6\end{array}$ & $\begin{array}{c}\text { Model } \\
7\end{array}$ & $\begin{array}{c}\text { Model } \\
8\end{array}$ & $\begin{array}{c}\text { Model } \\
9\end{array}$ & $\begin{array}{l}\text { Model } \\
10\end{array}$ & $\begin{array}{c}\text { Model } \\
11\end{array}$ & $\begin{array}{l}\text { Model } \\
12\end{array}$ \\
\hline \multicolumn{10}{|l|}{$\begin{array}{l}\text { Subjective Characteristics of } \\
\text { Urban Human Settlements }\end{array}$} \\
\hline Urban safety & & 0.399 & & & 0.652 & & & $0.361^{* * *}$ & \\
\hline Accessibility of public service facilities & & 0.128 & & & 2.399 & & & $2.777^{* * *}$ & \\
\hline Natural Environmental Comfort & & 0.588 & & & 0.567 & & & $1.781^{* * *}$ & \\
\hline Socio-humane environmental comfort & & 1.241 & & & 0.94 & & & 3.056 & \\
\hline Convenience of transportation & & $0.576 * *$ & & & 0.746 & & & 1.068 & \\
\hline Environmental health & & 1.806 & & & $0.555 * *$ & & & $2.379 * * *$ & \\
\hline \multicolumn{10}{|l|}{$\begin{array}{l}\text { Subjective Characteristics of } \\
\text { Urban Human Settlements }\end{array}$} \\
\hline Government Integrity & & & -0.005 & & & $\underset{* *}{-0.027}$ & & & $-0.030 * *$ \\
\hline Environmental protection & & & -0.011 & & & -0.010 & & & -0.018 \\
\hline The gap between rich and poor & & & $\begin{array}{c}-0.030 \\
* * *\end{array}$ & & & -0.014 & & & -0.013 \\
\hline Employment issue & & & $\underset{* * *}{-0.028}$ & & & $\underset{* *}{-0.026}$ & & & -0.002 \\
\hline Education and teaching & & & -0.001 & & & -0.003 & & & $-0.027^{* *}$ \\
\hline Medical issues & & & -0.008 & & & -0.017 & & & -0.023 \\
\hline Housing supply & & & -0.001 & & & -0.001 & & & -0.008 \\
\hline Social security & & & $\begin{array}{c}-0.230 \\
* * *\end{array}$ & & & -0.020 & & & -0.024 \\
\hline Medical satisfactions & & & $0.119^{* * *}$ & & & $0.103^{* * *}$ & & & 0.064 \\
\hline Medical level & & & 0.016 & & & 0.058 & & & 0.063 \\
\hline \multicolumn{10}{|l|}{ Residents' Personal Attributes } \\
\hline Gender & 0.047 & 0.047 & 0.030 & $0.080^{* *}$ & $0.086^{* *}$ & 0.057 & -0.021 & -0.025 & -0.044 \\
\hline Age & $0.120 * * *$ & $0.121 * * *$ & $0.111^{* * *}$ & $0.128^{* * *}$ & $0.132 * * *$ & $0.117^{* * *}$ & $0.169^{* * *}$ & $0.166^{* * *}$ & $0.156^{* * *}$ \\
\hline Educational background & -0.028 & -0.029 & -0.030 & 0.017 & 0.009 & 0.002 & 0.039 & 0.034 & 0.042 \\
\hline Marital status & -0.013 & -0.012 & 0.001 & -0.039 & -0.049 & -0.015 & -0.070 & -0.077 & -0.050 \\
\hline Income level & 0.022 & $0.032 * *$ & $0.024^{* *}$ & -0.017 & -0.004 & -0.010 & 0.016 & 0.027 & 0.017 \\
\hline Type of housing inhabited & -0.036 & -0.016 & -0.029 & 0.025 & 0.016 & 0.017 & $0.060^{* *}$ & $0.055^{* *}$ & $0.055^{* *}$ \\
\hline Health status & $0.194^{* * *}$ & $0.189 * * *$ & $0.179^{* * *}$ & $0.173^{* * *}$ & $0.469 * * *$ & $0.156^{* * *}$ & $0.160 * * *$ & $0.160 * * *$ & $0.149 * * *$ \\
\hline Constant & 3.12 & 2.35 & 2.80 & 3.10 & 2.68 & 2.62 & 3.04 & 8.29 & 2.94 \\
\hline F-test value & $22.58^{* * *}$ & $13.13^{* * *}$ & $12.81^{* * *}$ & $10.41^{* * *}$ & $6.41^{* * *}$ & $6.70^{* * *}$ & $8.96^{* * *}$ & $6.28^{* * *}$ & $5.73^{* * *}$ \\
\hline Adj R-squared & 0.684 & 0.712 & 0.889 & 0.458 & 0.488 & 0.659 & 0.512 & 0.624 & 0.723 \\
\hline
\end{tabular}




\subsubsection{Residents' Personal Attributes}

Models 4, 7 and 10 show that gender had a significant effect on the life satisfaction of residents in the central region at the $10 \%$ level, but not in the eastern and western regions. Age had a significant positive effect on the life satisfaction of residents across the entire region, passing the $1 \%$ significance level test, indicating that the older the residents are in the eastern, central and western regions, the higher their life satisfaction is. The effects of educational background, marital status and income level on the life satisfaction of residents in the entire region were not significant, but after adding the variables of objective and subjective characteristics of urban habitat environment, the income level passed the $5 \%$ significance level test in the eastern region. The type of housing inhabited had a significant effect on the life satisfaction of residents in the western region but had a weak effect on the life satisfaction of residents in the eastern and central regions. The effect of health status on the life satisfaction of residents across the entire region passed the $1 \%$ significance level test, with the most significant effect in the eastern region.

\subsubsection{Objective Characteristics of Urban Human Settlements}

Models 5, 8 and 11 show that the effects of urban safety, public service facility accessibility and natural environmental comfort on the life satisfaction of residents in the eastern and central regions are not significant; the effects on residents' life satisfaction in the western areas passed the $1 \%$ significance level, indicating that for each unit increase of urban safety, public service facility accessibility and natural environmental comfort, the life satisfaction of residents in the western region will increase by $0.361,2.777$ and 1.781 units, respectively. The social and cultural environment had no significant effect on the life satisfaction of residents in the entire region. The convenience of transportation had an obvious positive effect on residents' life satisfaction in the eastern region, passing the $5 \%$ significance level test. Environmental health had a significant positive effect on residents life satisfaction in the central and western regions and was significant at the $5 \%$ and $1 \%$ significance levels, respectively.

\subsubsection{Subjective Characteristics of Urban Human Settlements}

Models 6, 9 and 12 show that government integrity had a significant negative impact on residents' life satisfaction in the central and western regions, while environmental protection, medical problems, housing supply and medical level had no significant effects on residents' life satisfaction in the eastern, central and western regions. The gap between the rich and the poor had no significant effect on residents' life satisfaction in the central and western regions, but it still had a significant negative effect in the eastern region. Employment issues had a more significant impact on residents' life satisfaction in the eastern and central regions. Education and teaching had a significant negative impact on residents' life satisfaction in the western region. Social security passed the $1 \%$ significance level test in the eastern region. Medical satisfactions had a significant negative impact on residents' life satisfaction in both the eastern and central regions, especially in the central region.

In summary, the objective characteristics of the urban human settlements, subjective characteristics of the urban human settlements and residents' personal attributes have different degrees of influence on the life satisfaction of residents in different regions. In the process of human settlements construction, the eastern region has gathered a large number of factors and resources that have improved the objective and subjective characteristics of the urban human settlements by virtue of its location and development advantages; these have enhanced life satisfaction among the residents in the eastern region. The central and western regions are affected by resource endowment, economic level, policy orientation and other factors, which, to a certain extent, restrict the improvement of residents' life satisfaction in the central and western regions. Therefore, to improve residents' life satisfaction, we should focus on promoting the balanced development of regional social economies, increasing investment in environmental protection and shortening regional development 
gaps to improve the objective characteristics of the urban human settlements development level and residents' subjective perceptions of the urban human settlements.

\subsection{Spatial Heterogeneity Analysis of Urban Human Settlements on Life Satisfaction}

Based on the regression results of models 2 and 3, GWR analysis of the significant variables in objective and subjective characteristics of urban human settlements was conducted using ArcGIS to detect the spatial heterogeneity of the influence of urban human settlements on resident life satisfaction. The significant variables among the objective characteristics of urban human settlements were natural environmental comfort and environmental health. Among the subjective characteristics of urban human settlements, the significant variables were government integrity, environmental protection, wealth gap, employment problems, social security, medical satisfactions and medical level. The collinearity test was performed on the above indicators and the results are shown in Table 6; the variance inflation factor (VIF) of the index of the wealth gap and medical satisfactions was greater than 7.5, indicating that these explanatory variables were redundant. Therefore, they were removed and the remaining seven significant variables were analyzed using GWR.

Table 6. Collinearity test for significant variables.

\begin{tabular}{cccccc}
\hline Significant Variables & VIF & Significant Variables & VIF & Significant Variables & VIF \\
\hline Natural environmental comfort & 1.181 & Environmental protection & 1.455 & Social security & 1.699 \\
Environmental health & 1.689 & Wealth gap & 8.081 & Medical satisfactions & 7.884 \\
Government integrity & 3.119 & Employment problems & 2.924 & Medical level & 3.572 \\
\hline
\end{tabular}

The regression results showed that the model could explain $69.861 \%$ of the spatial variation in residents' life satisfaction. The adjusted $R^{2}$ was 0.607 and the condition number ranged from 19.960 to 20.011, indicating that the model passed the goodness-of-fit test through multicollinearity diagnosis. The multi-layer linear regression results had a certain degree of reliability. The degree of variation of each variable showed different characteristics (Figure 5).

(1) There was a positive correlation between the comfort of the natural environment and residents' life satisfaction in space. The effect level was prominent in space (the coefficient was $0.1050-0.2134$ ), showing a cascade structure decreasing from west to east in space (Figure 5a). The regions with strong effects were mainly located in Xinjiang and Tibet, indicating that the area should focus on meeting the ecological needs of residents and improving the comfort degree of the environment.

(2) The regression coefficients of environmental health were all positive, indicating that the health degree of the environment has a significant positive effect on residents' life satisfaction. The regression coefficient showed an increasing trend from northwest to southeast (Figure 5b). The high-value areas were mainly located in Zhejiang, Jiangxi, Fujian, Guangdong, Guangxi, Hainan and other provinces and low-value areas were mainly located in the central and western provinces such as Tibet, Xinjiang, Qinghai, Gansu, Ningxia, Inner Mongolia and Heilongjiang.

(3) There was a negative correlation between the degree of government integrity and residents' life satisfaction. The absolute value of the regression coefficient showed a decreasing trend from west to northeast and the spatial differentiation characteristics can be seen in Figure 5c. Its sensitive areas were mainly located in Yunnan, Tibet, Xinjiang and other provinces. Therefore, these places should focus on the macrocontrol role of the government and strengthening government integrity.

(4) Environmental protection had a blocking effect on residents' life satisfaction. The more serious the environmental problems, the lower the residents' life satisfaction The absolute value of the regression coefficient displays a stepped structure from northeast to south (Figure 5d). Among them, the areas most sensitive to environmental 
(5) The regression coefficient of the employment problem was negative, indicating that employment problems have an inhibitory effect on residents' life satisfaction. The severity of the employment problem can reduce the residents' life satisfaction. The regression coefficient showed a trend decreasing from west to east and had northsouth differentiation characteristics in the eastern region (Figure 5e). The regression coefficient was sensitive in the areas of Heilongjiang, Jilin and Liaoning, indicating that it should increase jobs, expand employment opportunities and alleviate the employment problem.

(6) Social security's impact on residents' life satisfaction showed a trend of changing layer by layer from south to north; high-value regions of the absolute values of the regression coefficients were found in Guangdong, Guangxi, Hainan and Fujian and low-value zones were found in Xinjiang, Inner Mongolia, Heilongjiang and Jilin, indicating that the impact of social security on residents' life satisfaction gradually decreased from south to north (Figure $5 \mathrm{f}$ ).

(7) The structure of the medical level on residents' life satisfaction originated from decreasing layer by layer from southeast to northwest, among which Shanghai, Zhejiang and Fujian were the most affected by medical level (Figure 5g). The regression coefficients of the medical level were all positive, indicating that medical level has a significant positive effect on residents' life satisfaction.

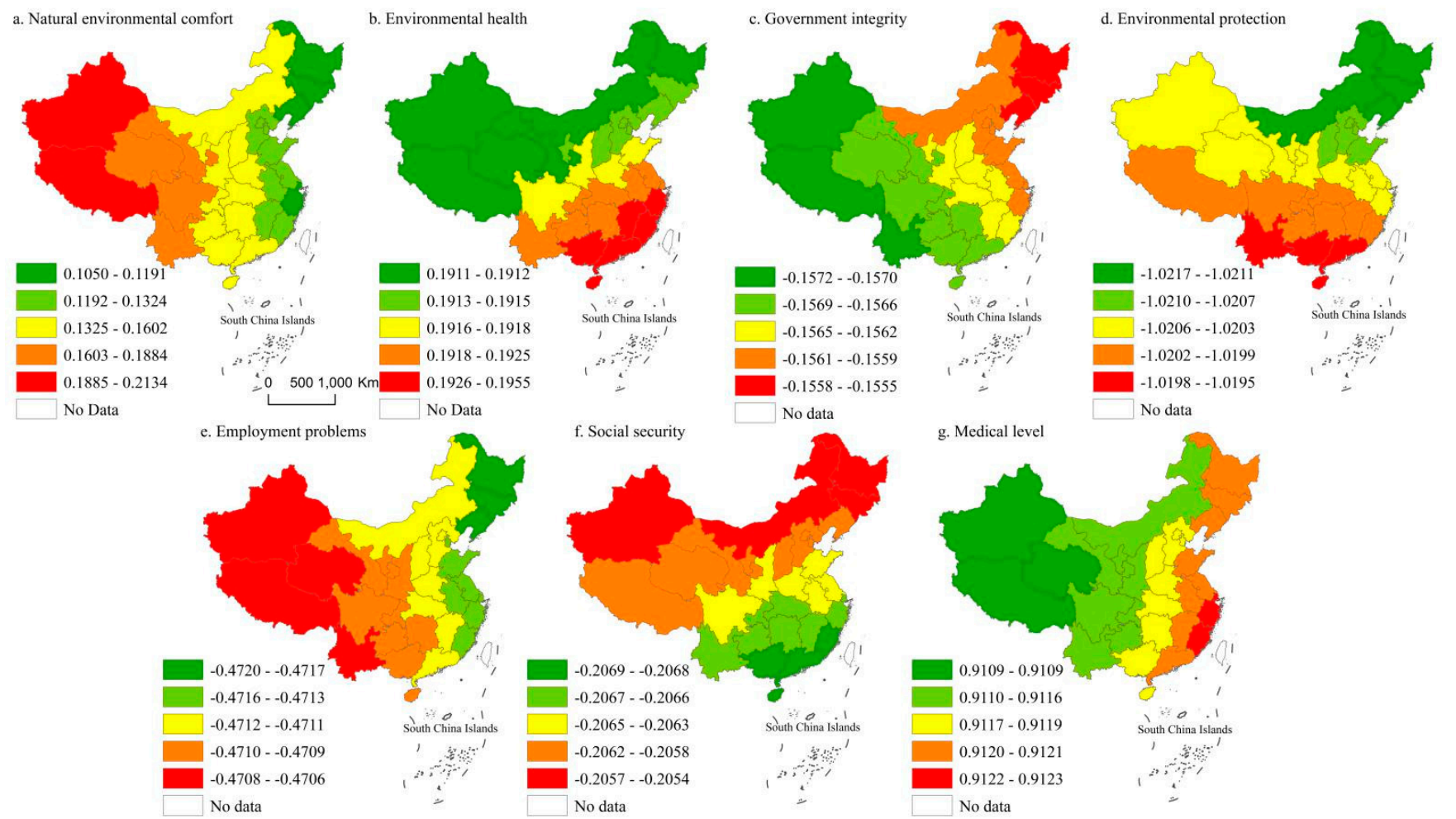

Figure 5. Spatial distribution of the regression coefficients estimated for significant variables.

\section{Discussion}

\subsection{Findings and Contributions}

As an evaluation index of residents' cognition of their own living conditions, residents' life satisfaction can directly reflect the development level of the social economy and implementation effect of government policies [48]. The focus of China's socialist construction work has gradually shifted from increasing residents' income to improving residents' life 
satisfaction. Only by fully studying the impact of the main and objective characteristics of urban human settlements on residents' life satisfaction can the overall connection between residents' life satisfaction and urban human settlements be effectively understood. This study provides a reference for improving residents' life satisfaction and people's livelihood.

Generally speaking, the overall level of residents' life satisfaction in 2018 was rated relatively high. Most ratings belonged to two types: quite satisfied and very satisfied. The average value of resident life satisfaction was 3.98, which is similar to Kang's results [81]. There is still large room for improvement in urban human settlements and it is necessary to continuously optimize urban human settlements to improve residents' living satisfaction. In addition, residents' life satisfaction varies according to population attributes such as age, marital status, income level and health conditions [83].

Theoretically, the study found a relationship between the subjective and objective characteristics of urban human settlements and the life satisfaction and the spatial heterogeneity of their influence. Previous research on life satisfaction at the macro scale mainly focused on the impact of the objective characteristics of urban human settlements on life satisfaction and ignored the subjective perceptions of the environment [83]. The core of urban human settlements is people and the main goal of urban planning and construction is to improve people's welfare. Therefore, we need to focus on the impact of residents' subjective perception factors on their life satisfaction. This study combined the subjective perception of urban human settlements with its objective characteristics to analyze its impact on residential life satisfaction, providing a new perspective on factors that influence life satisfaction.

In addition to verifying that the subjective and objective characteristics of urban human settlements have varying degrees of impact on residents' life satisfaction [84], the indexes were sufficiently detailed to explore the degree of influence of different indicators on residents' life satisfaction. The study found that among the objective characteristics of urban human settlements, the natural environmental comfort and health have a significant impact on residents' life satisfaction, which is consistent with the results of Wu. In addition, among the subjective characteristics of urban human settlements, government integrity, environmental protection, gap between rich and poor, social security, medical conditions and medical level are closely related to residents' life satisfaction. This shows that residents are more concerned about a fair, healthy and convenient living environment $[5,38,81]$.

This study provides a qualitative and quantitative analysis of the impact of the subjective and objective characteristics of urban human settlements on resident life satisfaction. On this basis, the theory of urban human settlements is enriched and expanded through empirical research. Additionally, this study further promotes the theoretical study of the influencing factors affecting the life satisfaction of Chinese urban residents.

\subsection{Optimization Measures}

In 2020, General Secretary Xi Jinping detailed at the Pudong Talk in Shanghai, China, that the core of urban construction is to help people live comfortably and have access to the best resources. This brings up a vital question: How does the government provide the best resources to the people and build a peaceful and livable city? It is necessary to start from the perspective of residents' subjective evaluations of their living environment. This paper examines the influence mechanism of subjective and objective characteristics of urban human settlements on residents' life satisfaction, explores residents' satisfaction with the construction of urban human settlements from a humanistic perspective and discusses how to improve the level of urban human settlements from the perspective of urban residents to build a better environment for common governance and sharing.

The objective characteristics of urban human settlements, such as the comfort of the natural environment and environmental health, are significantly related to residents' satisfaction. Therefore, in the process of building the habitat environment, attention should be focused on improving the construction of green space, improving the urban green space environment, developing clean energy and reducing pollution emissions through increased 
investment in science and technology. This will provide urban residents with a high-quality living environment and daily protection, thereby enhancing their satisfaction with life.

The impact of residents' perceptions of government integrity, environmental protection, wealth gap, social security, access to healthcare and medical care in the urban human settlements on their life satisfaction passed the significance level test; therefore, attention should focused on the construction of the medical environment, the improvement of government work supervision mechanisms and the social security system, the promotion of a balanced flow of socio-economic factors, the narrowing of the wealth gap and coordinated regional development.

In addition, the impact of the objective and subjective characteristics of urban human settlements on the life satisfaction of residents is reflected at the macro level as differences in the direction and strength of the impact between different regions, which is due to unbalanced allocation of resource factors over a long period. Therefore, it is necessary to strengthen regional communication and cooperation and promote the flow of resource elements between regions to account for regional development in the process of human settlement environment construction.

\subsection{Limitations}

There were shortcomings in this study that need to be explored in depth in the future. First, this study only explored the influence mechanism of urban human settlements on residents' life satisfaction from an overall perspective. It did not explore urban agglomeration and provinces. Second, residents' life satisfaction is also influenced by personal elements such as self-selective behavior and psychological factors; therefore, more in-depth interviews and empirical studies are needed. Third, this paper is only a horizontal study of a single year. An empirical study of long time series should be performed in the future to provide a theoretical basis for optimizing urban human settlements and improving residents' life satisfaction.

\section{Conclusions}

In the context of China's rapid urbanization, research on the urban human settlements and residents' life satisfaction has attracted widespread attention from an increasing number of scholars $[62,70]$. This study focused on residents' life satisfaction, used multi-layer linear regression models to analyze the influence of objective and subjective characteristics of urban human settlements and used geographically weighted regression models to analyze the spatial heterogeneity of these effects. It is a comprehensive practice of research theory, research and application of life satisfaction. It is of great significance to the study life satisfaction and urban human settlements planning.

The study found that the objective characteristics of the urban human settlements, subjective characteristics of the urban human settlements and personal attributes have various effects on life satisfaction in different areas. Among them, improvement of the natural environmental comfort was conducive to the improvement of residents' life satisfaction, especially in the western region. The impacts of environmental health and medical levels were more pronounced in the southeast region. The degree of government integrity had a significant impact on the life satisfaction of residents in western China. The expansion of environmental protection and the severity of employment problems had an inhibitory effect on improving the life satisfaction of residents in northeast China. The southern region should focus more on social security issues.

However, the study only initially explores the strength and direction of the influence of the subjective and objective characteristics of urban human settlements on life satisfaction. The influencing factors of life satisfaction represent the interaction and attention should focused on the superimposed effect of influencing factors. Therefore, in future research, the mechanisms through which objective environmental characteristics and subjective perception characteristics of urban human settlements influence residents' life satisfaction should be deeply explored. By analyzing their internal mechanisms and discussing how 
objective characteristics of the urban human settlements, subjective characteristics of the urban human settlements and residents' personal attributes interact and influence residents' life satisfaction, we can better understand how to change the living environment to improve residents' life satisfaction and provide a theoretical basis for urban human settlements reconstruction.

Author Contributions: Conceptualization, H.L.; methodology, H.L.; software, H.L.; validation, H.L. and X.L.; formal analysis, H.L.; investigation, H.L.; resources, H.L.; data curation, H.L.; writingoriginal draft preparation, H.L.; writing-review and editing, X.L.; visualization, H.L.; supervision, X.L.; project administration, X.L.; funding acquisition, X.L. All authors have read and agreed to the published version of the manuscript.

Funding: This research was funded by the National Natural Science Foundation of China (grant number 41671158).

Institutional Review Board Statement: Not applicable.

Informed Consent Statement: Not applicable.

Data Availability Statement: The data presented in this study, are available on request from the corresponding author.

Acknowledgments: The authors would like to thank residents who participated in the 2018 CFPS. The authors would like to thank Institute of Social Science Survey, Peking University for providing the datasets and codebook for data analysis of 2018 CFPS.

Conflicts of Interest: The authors declare no conflict of interest.

\section{References}

1. Diener, E.; Oishi, S.; Lucas, R.E. Personality, culture, and subjective well-being: Emotional and cognitive evaluations of life. Annu. Rev. Psychol. 2003, 54, 403-425. [CrossRef]

2. Diener, E.; Chan, M.Y. Happy People Live Longer: Subjective Well-Being Contributes to Health and Longevity. Appl. Psychol. Health Well-Being 2011, 3, 1-43. [CrossRef]

3. Chen, J.; Chen, S. Mental health effects of perceived living environment and neighborhood safety in urbanizing China. Habitat Int. 2015, 46, 101-110. [CrossRef]

4. Cao, X.J. How does neighborhood design affect life satisfaction? Evidence from Twin Cities. Travel Behav. Soc. 2015, 51, 68-76. [CrossRef]

5. Li, H.; Li, X.; Tian, S.; Li, S.; Zhao, P. Temporal and spatial variation characteristics and mechanism of urban human settlements: Case study of Liaoning province. Geogr. Res. 2017, 36, 1323-1338. [CrossRef]

6. Tian, S.; Li, X.; Li, H.; Zhang, Y.; Bao, T. Initial Evaluation of Provincial-Level Environmental Risks from the Perspective of Human Settlements. Sustainability 2016, 8, 1259. [CrossRef]

7. Tian, S.; Li, X.; Yang, J.; Zhang, C.; Zhang, Y. Initial Study on Triaxiality of Human Settlements-In the Case of 10 Districts (Counties) of Dalian. Sustainability 2014, 6, 7276-7291. [CrossRef]

8. Yang, J.; Wang, Y.; Xiao, X.; Jin, C.; Xia, J.; Li, X. Spatial differentiation of urban wind and thermal environment in different grid sizes. Urban Clim. 2019, 28, 100458. [CrossRef]

9. Cong, X.; Li, X.; Gong, Y. Spatiotemporal Evolution and Driving Forces of Sustainable Development of Urban Human Settlements in China for SDGs. Land 2021, 10, 993. [CrossRef]

10. Xiao, Y.; Wang, J.; Huang, H. Does economic development bring more livability? Evidence from Jiangsu Province, China. J. Clean. Prod. 2021, 293, 126187. [CrossRef]

11. Li, G.; Jiang, C.; Du, J.; Jia, Y.; Bai, J. Spatial differentiation characteristics of internal ecological land structure in rural settlements and its response to natural and socio-economic conditions in the Central Plains, China. Sci. Total Environ. 2020, 709, 135932.1-135932.10. [CrossRef]

12. Qu, L.; Li, Y.; Feng, W. Spatial-temporal differentiation of ecologically-sustainable land across selected settlements in China: An urban-rural perspective. Ecol. Indic. 2020, 112, 105783. [CrossRef]

13. Ma, J.; Dong, G.; Chen, Y.; Zhang, W. Does satisfactory neighbourhood environment lead to a satisfying life? An investigation of the association between neighbourhood environment and life satisfaction in Beijing. Cities 2017, 74, 229-239. [CrossRef]

14. Park, K.; Ewing, R.; Scheer, B.C.; Tian, G. The impacts of built environment characteristics of rail station areas on household travel behavior. Cities 2018, 74, 277-283. [CrossRef]

15. Sun, B.; Yin, C. Relationship between multi-scale urban built environments and body mass index: A study of China. Appl. Geogr. 2018, 94, 230-240. [CrossRef] 
16. Cao, J.; Ettema, D. Satisfaction with travel and residential self-selection: How do preferences moderate the impact of the Hiawatha Light Rail Transit line? J. Transp. Land Use 2014, 7, 93-108. [CrossRef]

17. Ballas, D. What makes a 'happy city'? Cities 2013, 32, S39-S50. [CrossRef]

18. Ballas, D.; Tranmer, M. Happy People or Happy Places? A Multilevel Modeling Approach to the Analysis of Happiness and Well-Being. Int. Reg. Sci. Rev. 2012, 35, 70-102. [CrossRef]

19. Carr, L.J.; Dunsiger, S.I.; Marcus, B.H. Walk Score (TM) As a Global Estimate of Neighborhood Walkability. Am. J. Prev. Med. 2010, 39, 460-463. [CrossRef]

20. Ziółkowska-Weiss, K. Satisfaction with Selected Indicators of the Quality of Urban Space by Polonia in the Greater Toronto Area. Land 2021, 10, 778. [CrossRef]

21. Vstfjll, D.; Friman, M.; Grling, T.; Kleiner, M. The measurement of core affect: A Swedish self-report measure derived from the affect circumplex. Scand. J. Psychol. 2002, 43, 19-31. [CrossRef]

22. Ambrey, C.; Fleming, C. Public Greenspace and Life Satisfaction in Urban Australia. Urban Stud. 2014, 51, 1290-1321. [CrossRef]

23. Kothencz, G.; Kolcsár, R.; Cabrera-Barona, P.; Szilassi, P. Urban Green Space Perception and Its Contribution to Well-Being. Int. J. Environ. Res. Public Health 2017, 14, 766. [CrossRef]

24. Fleming, C.M.; Manning, M.; Ambrey, C.L. Crime, greenspace and life satisfaction: An evaluation of the New Zealand experience. Landsc. Urban Plan. 2016, 149, 1-10. [CrossRef]

25. Bonaiuto, M.; Fornara, F.; Ariccio, S.; Cancellieri, U.G.; Rahimi, L. Perceived Residential Environment Quality Indicators (PREQIs) relevance for UN-HABITAT City Prosperity Index (CPI). Habitat Int. 2015, 45, 53-63. [CrossRef]

26. Mao, Z; Wang, D. Residential relocation and life satisfaction change: Is there a difference between household couples? Cities 2020, 97, 102565. [CrossRef]

27. Florida, R.; Mellander, C.; Rentfrow, P.J. The happiness of cities. Reg. Stud. 2013, 47, 613-627. [CrossRef]

28. Ettema, D.; Schekkerman, M. How do spatial characteristics influence well-being and mental health? Comparing the effect of objective and subjective characteristics at different spatial scales. Travel Behav. Soc. 2015, 5, 56-67. [CrossRef]

29. Zijlema, W.L.; Wolf, K.; Emeny, R.; Ladwig, K.H.; Peters, A.; Kongsgard, H.; Hveem, K.; Kvaloy, K.; Yli-Tuomi, T.; Partonen, T. The association of air pollution and depressed mood in 70,928 individuals from four European cohorts. Int. J. Hyg. Environ. Health 2016, 219, 212-219. [CrossRef]

30. Firdaus, G. Built Environment and Health Outcomes: Identification of Contextual Risk Factors for Mental Well-being of Older Adults. Ageing Int. 2016, 42, 62-77. [CrossRef]

31. Jones-Rounds, M.L.; Evans, G.W.; Braubach, M. The interactive effects of housing and neighbourhood quality on psychological well-being. J. Epidemiol. Community Health 2014, 68, 171-175. [CrossRef] [PubMed]

32. Mikucka, M.; Sarracino, F.; Dubrow, J.K. When Does Economic Growth Improve Life Satisfaction? Multilevel Analysis of the Roles of Social Trust and Income Inequality in 46 Countries, 1981-2012. World Dev. 2017, 93, 447-459. [CrossRef]

33. Hamersma, M.; Tillema, T.; Sussman, J.; Arts, J. Residential satisfaction close to highways: The impact of accessibility, nuisances and highway adjustment projects. Transp. Res. Part A Policy Pract. 2014, 59, 106-121. [CrossRef]

34. Zhou, K.; Tan, J.; Watanabe, K. How does perceived residential environment quality influence life satisfaction? Evidence from urban China. J. Community Psychol. 2021, 49, 2454-2471. [CrossRef] [PubMed]

35. Gao, M.; Ahern, J.; Koshland, C.P. Perceived built environment and health-related quality of life in four types of neighborhoods in Xi'an, China. Health Place 2016, 39, 110-115. [CrossRef]

36. Feng, J.; Lin, W. Residential satisfaction level and influencing factors of declining old town residents in Suzhou. Prog. Geogr. 2017, 36, 159-170. [CrossRef]

37. Hur, M.; Morrow-Jones, H. Factors That Influence Residents' Satisfaction with Neighborhoods. Environ. Behav. 2008, 40, 619-635. [CrossRef]

38. Dyck, D.V.; Teychenne, M.; Mcnaughton, S.A.; Bourdeaudhuij, I.D.; Salmon, J. Relationship of the Perceived Social and Physical Environment with Mental Health-Related Quality of Life in Middle-Aged and Older Adults: Mediating Effects of Physical Activity. PLoS ONE 2015, 10, e120475. [CrossRef]

39. White, M.J.; Hunter, L.M. Public Perception of Environmental Issues in a Developing Setting: Environmental Concern in Coastal Ghana. Soc. Sci. Q. 2010, 90, 960-982. [CrossRef]

40. Kshetrimayum, B.; Bardhan, R.; Kubota, T. Factors Affecting Residential Satisfaction in Slum Rehabilitation Housing in Mumbai. Sustainability 2020, 12, 2344. [CrossRef]

41. Jiboye, A.D. Post-occupancy evaluation of residential satisfaction in Lagos, Nigeria: Feedback for residential improvement. Front. Archit. Res. 2012, 1, 236-243. [CrossRef]

42. Clark, A.; Frijters, P.; Shields, M.A. Relative Income, Happiness and Utility: An Explanation for the Easterlin Paradox and Other Puzzles. Soc. Sci. Electron. Publ. 2008, 46, 95-144. [CrossRef]

43. Tella, R.D.; New, H.D.; M Ac Culloch, R. Happiness Adaptation to Income and to Status in an Individual Panel. J. Econ. Behav. Organ. 2010, 76, 834-852. [CrossRef]

44. Arifwidodo, S.D.; Perera, R. Quality of Life and Compact Development Policies in Bandung, Indonesia. Appl. Res. Qual. Life 2011, 6, 159-179. [CrossRef]

45. Pickard, A.S.; Jalundhwala, Y.J.; Bewsher, H.; Sharp, L.K.; Walton, S.M.; Schumock, G.T.; Caskey, R.N. Lifestyle-related attitudes: Do they explain self-rated health and life-satisfaction? Qual. Life Res. 2018, 27, 1227-1235. [CrossRef] 
46. Sugiyama, T.; Thompson, C.W.; Alves, S. Associations between Neighborhood Open Space Attributes and Quality of Life for Older People in Britain. Environ. Behav. 2009, 41, 3-21. [CrossRef]

47. Tong, W.; Lo, K.; Zhang, P. Land Consolidation in Rural China: Life Satisfaction among Resettlers and Its Determinants. Land 2020, 9, 118. [CrossRef]

48. Shen, Z.; Zheng, X.; Yang, H. The fertility effects of public pension: Evidence from the new rural pension scheme in China. PLoS ONE 2020, 15, e234657. [CrossRef]

49. Liu, Z.; Li, Q.; Lan, J.; Millington, A. The Mediating Role of Social Capital in Digital Information Technology Poverty Reduction an Empirical Study in Urban and Rural China. Land 2021, 10, 634. [CrossRef]

50. Zheng, Q.; Peng, Z.; Ding, S. Financial Literacy, Health Engagement, and Residents' Health: Evidence from China. Int. J. Environ. Res. Public Health 2021, 18, 4202. [CrossRef]

51. Ding, Y.; Shi, B.; Su, G.; Li, Q.; Meng, J.; Jiang, Y.; Qin, Y.; Dai, L.; Song, S. Assessing Suitability of Human Settlements in High-Altitude Area Using a Comprehensive Index Method: A Case Study of Tibet, China. Sustainability 2021, 13, 1485. [CrossRef]

52. Ibem, E.O.; Amole, D. Subjective life satisfaction in public housing in urban areas of Ogun State, Nigeria. Cities 2013, 35, 51-61. [CrossRef]

53. Mackerron, G.; Mourato, S. Life satisfaction and air quality in London. Ecol. Econ. 2009, 68, 1441-1453. [CrossRef]

54. Dawson, M.; Abbott, J.; Shoemaker, S. The Hospitality Culture Scale: A measure organizational culture and personal attributesScienceDirect. Int. J. Hosp. Manag. 2011, 30, 290-300. [CrossRef]

55. Mussen, P.; Honzik, M.P.; Eichorn, D.H. Early Asult Antecedents of Life Satisfaction at Age 70. Life-Span Chang. A Gerontol. Perspect. 1985, 37, 45-61. [CrossRef]

56. Guo, M. Parental status and late-life well-being in rural China: The benefits of having multiple children. Aging Ment. Health 2014, 18, 19-29. [CrossRef]

57. Marzluff, J.M.; Neatherlin, E. Corvid response to human settlements and campgrounds: Causes, consequences, and challenges for conservation. Biol. Conserv. 2006, 130, 301-314. [CrossRef]

58. Song, F.; Yang, X.; Wu, F. Suitable Pattern of the Natural Environment of Human Settlements in the Lower Reaches of the Yangtze River. Atmosphere 2019, 10, 200. [CrossRef]

59. Feng, Z.; Yang, Y.; Zhang, D.; Tang, Y. Natural environment suitability for human settlements in China based on GIS. J. Geogr. Sci. 2009, 19, 437-446. [CrossRef]

60. Baskin, M.L.; Dulin-Keita, A.; Thind, H.; Godsey, E. Social and Cultural Environment Factors Influencing Physical Activity among African-American Adolescents. J. Adolesc. Health 2015, 56, 536-542. [CrossRef]

61. Cong, X.; Li, X.; Li, S.; Gong, Y. Research on Sustainable Development Ability and Spatial-Temporal Differentiation of Urban Human Settlements in China and Japan Based on SDGs, Taking Dalian and Kobe as Examples. Complexity 2021, $2021,8876021$. [CrossRef]

62. Xue, Q.; Yang, X.; Wu, F. A two-stage system analysis of real and pseudo urban human settlements in China. J. Clean. Prod. 2021, 293, 126272. [CrossRef]

63. Chen, Y.; Mei, L.; Hu, Y.; Wang, T. Comprehensive Measures and Improvement Path of Residential Suitability in Northeast China. Resour. Dev. Mark. 2016, 32, 14-17. [CrossRef]

64. Chen, S.; Liu, Z. What determines the settlement intention of rural migrants in China? Economic incentives versus sociocultural conditions-ScienceDirect. Habitat Int. 2016, 58, 42-50. [CrossRef]

65. Pawowska, K. The smells of Neolithic atalhyük, Turkey: Time and space of human activity. J. Anthropol. Archaeol. 2014, 36, 1-11. [CrossRef]

66. Lowenstein, A.; Katz, R. Living arrangements, family solidarity and life satisfaction of two generations of immigrants in Israel. Ageing Soc. 2005, 25, 749-767. [CrossRef]

67. Bo, L.; Jin, X. Spatio-temporal Evolution of Marine Fishery Industry Ecosystem Vulnerability in the Bohai Rim Region. Chin. Geogr. Sci. 2019, 29, 150-162. [CrossRef]

68. Zheng, G.; Li, C.; Feng, Y. Developing a new index for evaluating physiological safety in high temperature weather based on entropy-TOPSIS model-A case of sanitation worker. Environ. Res. 2020, 191, 110091. [CrossRef]

69. Li, X.; Li, S.; Gao, J.; Zhao, P.; Hang, L. Human Settlement Quality Evaluation Based on Air Quality in Major Cities of China. Adv. Meteorol. 2018, 2018, 1-9. [CrossRef]

70. Yang, X.; Li, Z.; Zhang, J.; Li, H. Spatiotemporal evaluation of urban resilience from the perspective of sustainable development. Urban Probl. 2021, 3, 29-37. [CrossRef]

71. Di, F. Relations among the behavior attitude, lifestyle, the sense of happiness and residents' environmental behavior in China: Based on CGSS2013 data. J. Arid. Land Resour. Environ. 2018, 32, 7-11. [CrossRef]

72. Fotheringham, A.S.; Charlton, M.E.; Brunsdon, C. Geographically Weighted Regression: A Natural Evolution Of The Expansion Method for Spatial Data Analysis. Environ. Plan. A 1998, 30, 1905-1927. [CrossRef]

73. Knight, J.; Song, L.; Gunatilaka, R. Subjective well-being and its determinants in rural China. China Econ. Rev. 2009, 20, 635-649. [CrossRef]

74. Dolan, P.; Peasgood, T.; White, M. Do we really know what makes us happy? A review of the economic literature on the factors associated with subjective well-being-ScienceDirect. J. Econ. Psychol. 2008, 29, 94-122. [CrossRef] 
75. Li, W.; Sun, H.; Xu, W.; Ma, W.; Kou, C. Individual Social Capital and Life Satisfaction among Mainland Chinese Adults: Based on the 2016 China Family Panel Studies. Int. J. Environ. Res. Public Health 2021, 18, 441. [CrossRef]

76. Zullig, K.J.; Valois, R.F.; Huebner, E.S.; Drane, J.W. Adolescent health-related quality of life and perceived satisfaction with life. Qual. Life Res. 2005, 14, 1573-1584. [CrossRef]

77. Kaplan, S. The Restorative Benefits of Nature: Toward an Integrative Framework. J. Environ. Psychol. 1995, 15, 169-182. [CrossRef]

78. Sullivan, W.C.; Kuo, F.E.; Depooter, S.F. The Fruit of Urban Nature. Environ. Behav. 2004, 36, 678-700. [CrossRef]

79. Jing, M.; Li, C.; Mei-Po, K.; Chai, Y. A Multilevel Analysis of Perceived Noise Pollution, Geographic Contexts and Mental Health in Beijing. Int. J. Environ. Res. Public Health 2018, 15, 1479. [CrossRef]

80. Lovejoy, K.; Handy, S.; Mokhtarian, P. Neighborhood satisfaction in suburban versus traditional environments: An evaluation of contributing characteristics in eight California neighborhoods. Landsc. Urban Plan. 2010, 97, 37-48. [CrossRef]

81. Kang, L.; Zhang, W.; Yang, Z.; Dang, Y. The Influences of Beijing's Built Environment on Residents' Livability Satisfaction. Hum. Geogr. 2020, 3, 52-60. [CrossRef]

82. Zhan, D.; Meng, B.; Zhang, W. A study on residential satisfaction and its behavioral intention in Beijing. Geogr. Res. 2014, 33, 336-348.

83. Shen, Y.; Fu, X. Impact of the built environment and perceived neighborhood characteristics on residents' satisfaction: Evidence from the Shanghai suburbs. Prog. Geogr. 2019, 38, 686-697. [CrossRef]

84. Wu, F. Neighborhood Attachment, Social Participation, and Willingness to Stay in China's Low-Income Communities. Urban Aff. Rev. 2012, 48, 547-570. [CrossRef] 